\title{
Modelling of a CHP SOFC System Fed with Biogas from Anaerobic Digestion of Municipal Waste Integrated with Solar Collectors and Storage Unit*
}

\author{
Domenico Borello $^{\mathrm{a}^{* *},}$, Sara Evangelisti ${ }^{\mathrm{b}}$ and Eileen Tortora ${ }^{\mathrm{c}}$ \\ âDIMA Sapienza Università di Roma, Roma,Italy, domenico.borello@ uniroma1.it \\ ${ }^{\mathrm{b}}$ CIRPS Sapienza Università di Roma, Roma, Italy,sara.evangelisti@uniroma1.it, \\ 'DIMA Sapienza Università di Roma , Roma,Italy, eileen.tortora@uniroma1.it
}

\begin{abstract}
The paradigm of the sustainable energy community is recognized as the future energy approach due to its economical, technical and environmental benefits. The analysed system is a waste-to-energy combined heat and power (CHP) generation plant that perfectly fits in the sustainable energy community paradigm. The power system is divided in the following sections: a) a mesophilic - single phase anaerobic digestion of Organic Fraction of Municipal Solid Waste for biogas production; b) a fuel treatment section with desulphurizer and pre-reformer units; c) a Solid Oxide Fuel Cell (SOFC) for CHP production; d) a solar collector integrated system(integrated storage system - ISS). An integrated TRNSYS/Aspen Plus model for simulating the power system behaviour during a typical reference period (day or year) was developed and presented. The proposed ISS consists of a solar collector integrated with storage systems system designed to continuously provide the thermal power required by the anaerobic digester.
\end{abstract}

Keywords: Distributed generation; anaerobic digestion; fuel cells; transient model; waste-to-energy; integrated TRNSYS/Aspen Plus model.

\section{Introduction}

The new trend in power generation drives toward distributed power generation (Alanne and Saari, 2006) The term distributed generation (DG) (Ackermann et al., 2001) indicates that the energy conversion units are situated close to energy consumers using small power unit when compared to the usual plants used for large scale production. Among the several definitions of distributed generation power unit rating we selected the one that indicates power plants from $1 \mathrm{~W}$ to $300 \mathrm{MW}$ of capacity, depending of the number of units connected in a modular form. Based on the classification of (Elkhattam and Salama, 2004), the system rating here analyzed is a small capacity (5 kW:5 MW).

DG approach should be recognized as the new future power paradigm due to the economic, technical and environmental benefits it achieves (Manfren et al., 2011). Application of DG means that single urban districts could be, in the future, self-supported in terms of electricity, heat and cooling energy.

This is in contrast with the facilities present to date, which concentrate the production of goods, thermal and electrical energy in large plants operating in a central location and connected with the final users via transmission and distribution networks. The centralized generation paradigm shows strong limitations due to the vulnerability of complex systems and the scarcity of the fossil fuels commonly used in large scale plants. On the contrary, small scale plant can advantageously use fuels locally available, often produced by Renewable Energy Sources (RES), e.g. biogas from wastes and wood biomass, improving the sustainability of the power generation.
In the European Union (EU), the path toward future energy systems has been clearly underlined with several directives (2002, 2006, 2009), research initiatives (C(2011)9493, COM(2009) 519, COM (2007, and short terms energy initiatives (cutting greenhouse gases emissions by 20\%, 20\% share of RES in EU energy consumption, cutting energy consumption through improved energy efficiency by $20 \%$ ). The success of DG systems is strongly subjected to their ability to use the waste heat from electricity generation as a heat source, obtaining total system efficiencies up to $90 \%$ (Strachan and Farrel, 2006). These applications, commonly called Combined Heat and Power (CHP) can lead to significant reductions of $\mathrm{CO}_{2}$ emissions.

Future systems should integrate renewable energy systems applying a "community-scale" approach to maximize energy performances, while minimizing environmental impacts. Efforts have to be directed toward the promotion of integrated technical systems needed to expand the use of renewable energy resources, to build sustainable local and national energy networks, to guarantee distribution systems for urban facilities and to reduce pollution. In this framework poly-generation is a promising design perspective, for building and district scale applications, in particular where different types of energy demand are simultaneously present and when sufficient energy intensity justifies investments in smart grids and district heating networks.

This study considers settlements of various types (residential, commercial, industrial), in which, through a mix of technological solutions, the interaction between fuel production and local electric and thermal energy generation will be optimized, reducing fossil fuel consumption and

*This paper is an updated version of a paper published in the ECOS'12 proceedings. It is printed here with permission of the authors and organizers. 
applying renewable sources. Poly-generation is then a possible solution, especially when different types of energy are requested at the same time and different sources - such as solar power and waste in this case - are available.

The system presented in this paper is based on the use of Organic Fraction of Municipal Solid Waste (OFMSW), (Eriksson et al., 2011) for the generation of biogas, through an anaerobic digestion process integrated with the heat produced by an array of solar collectors as cycle preheating, in order to feed Solid Oxide Fuel Cells for the electric and thermal power generation. This enhances the system sustainability in terms of use of renewable sources and of efficient waste management. Production and collection of OFMSW takes place at district level where energy demands occur, making it a potential non-seasonal energy feedstock (Gregg, 2010). Moreover, using OFMSW for energy reduces land demands for waste disposal sites near urban areas where land pressures are high. The biogas can then be used as fuel for energy production, through several energy systems. Furthermore biogas is an alternative to natural gas and reduces the amount of greenhouse gas (GHG), since the carbon dioxide produced by the combustion of biogas is considered biogenic and does not contribute to the global warming (Morin et al., 2010).

In situ anaerobic digestion of biomass and organic waste has the potential to provide sustainable distributed generation of electric power together with a viable solution for the disposal of municipal solid wastes. A thermal recovery system can provide the heat required for districtheating. The biogas can be efficiently used to feed an internal combustion engine for CHP. However, the need to increase the electrical efficiency of the system leads to the adoption of equipment with higher conversion efficiency.

Fuel cells are very promising energy conversion devices: they show a very high electrical efficiency, no moving parts and - important for the sustainability - zero emissions at the point of use when fed with biogas. Among the different types of fuel cells commercially available, low temperature Polymeric Electrolyte Membrane Fuel Cell (PEMFC) and high temperature Solid Oxide Fuel Cells (SOFC) are considered reliable to be applicable for DG (Calise, 2011). Despite a relatively low capital cost, PEMFC requires pure hydrogen to be fed. Therefore biogas must be converted to $\mathrm{H}_{2}$-rich gas before feeding the PEMFC, using reformer and CO removal. This dramatically increases the system complexity and decreases the overall electrical efficiency. On the other hand, SOFC are very flexible in burning several type of fuels due to the high working temperatures $\left(700-1000^{\circ} \mathrm{C}\right)$ that allow them to convert hydrocarbons into hydrogen internally, with an overall electrical efficiency of about 55-60\% even when fed by methane or biogas (Larminie and Dicks, 2004, Shiratori et al., 2008). Moreover the absence of moving component (reducing mechanical stresses, noises and vibrations) and the small efficiency reduction when working in off-design conditions represent relevant advantages of this technology. Finally this efficiency can be even higher- up to $70 \%$ (Calise et al., 2006) - when SOFCs are coupled with gas turbine or organic Rankine cycle turbine in hybrid cycles. Due to their modularity, SOFC can be easily integrated in combine heat and power plants, reaching very high global efficiency (around $80 \%$ ) (Liso et al., 2011). However, many developments are needed to increase the reliability of such systems before SOFCs can become economically competitive with ICE alternatives.

This study aims at analysing a community scale polygeneration energy system, through an integrated TRNSYS/Aspen Plus model. The system is composed by four main units: a) a mesophile - single phase anaerobic digester of Organic Fraction of Municipal Solid Waste for biogas production; b) a fuel treatment section with fuel steam reforming; c) a Solid Oxide Fuel Cell for CHP production; d) a solar collector systems to supply heat to the anaerobic digester. The anaerobic digester process needs a constant temperature in order to maximize the biogas production. The heat demand can be supplied in different ways, generally with a furnace that uses the biogas as fuel source. The low price of solar collectors and the sun availability as energy source in the Mediterranean area supports the idea to use solar thermal collectors to maintain the desired constant temperature inside the digester.

\section{Description of the System}

The studied scenario is representative of a communityscale plant, serving a hypothetical urban group of 50 families. The estimated electric power is set equal to 150 $\mathrm{kW}$ and it is delivered by a SOFC fed with biogas from anaerobic digester operating in the range $35^{\circ} \mathrm{C}$ to $45^{\circ} \mathrm{C}$ (mesophilic conditions). To compensate the heat losses and to heat up the substrate, a continuous feed of heat to the digester is required. No waste pre-treatment processes are considered in this analysis.

In the poly-generation system considered solar thermal collectors are considered as complementary heat source for the digester (Axaopoulos et al., 2001), (Alkhamis et al., 2001). This heat feeds a thermal energy storage (TES), eventually integrated with heat produced by a biomass furnace, when the solar source is not sufficient.

The heat power obtained from the conversion process in the SOFC section, about $70 \mathrm{~kW}$, is primarily used by the same SOFC for maintaining the reformer temperature (28.4 $\mathrm{kW}$ ) heating the fuel inlet stream at the anode side (34.7 $\mathrm{kW}$ ), while about $7 \mathrm{~kW}$ remains and they can eventually be used to feed end-users. Downstream from the afterburner $240.5 \mathrm{~kW}$ will be used to feed the air inlet stream at the cathode. Another end-user is successively fed with the residual heat $(12.57 \mathrm{kWth})$ is delivered to the final user to integrate a district heating system (not specified here). It is important to point out that we assumed to feed an end-user that requires steam at $120^{\circ} \mathrm{C}$. Then the exhausts will be released at $400 \mathrm{~K}$. Then a certain amount of heat power is available for eventual end-user requiring hot water at lower temperature.

\section{Methodology}

In order to evaluate the time-dependent behaviour and the performance of the proposed system a transient model is developed in the TRNSYS framework (Klein et al., 2000).To the best of the author knowledge few studies have appeared to date in the open literature, that propose the use of TRNSYS-framed models for complex energy systems. Some of the exceptions deal with studies on renewable energy system integration in grid-connected or stand-alone power systems (Quesada et al., 2011), (Corsini et al., 2009). Some studies deal with the integration of fuel cells in buildings energy systems (Dorer et al., 2005) and polygeneration systems with solar collectors (Calise, 2011). 


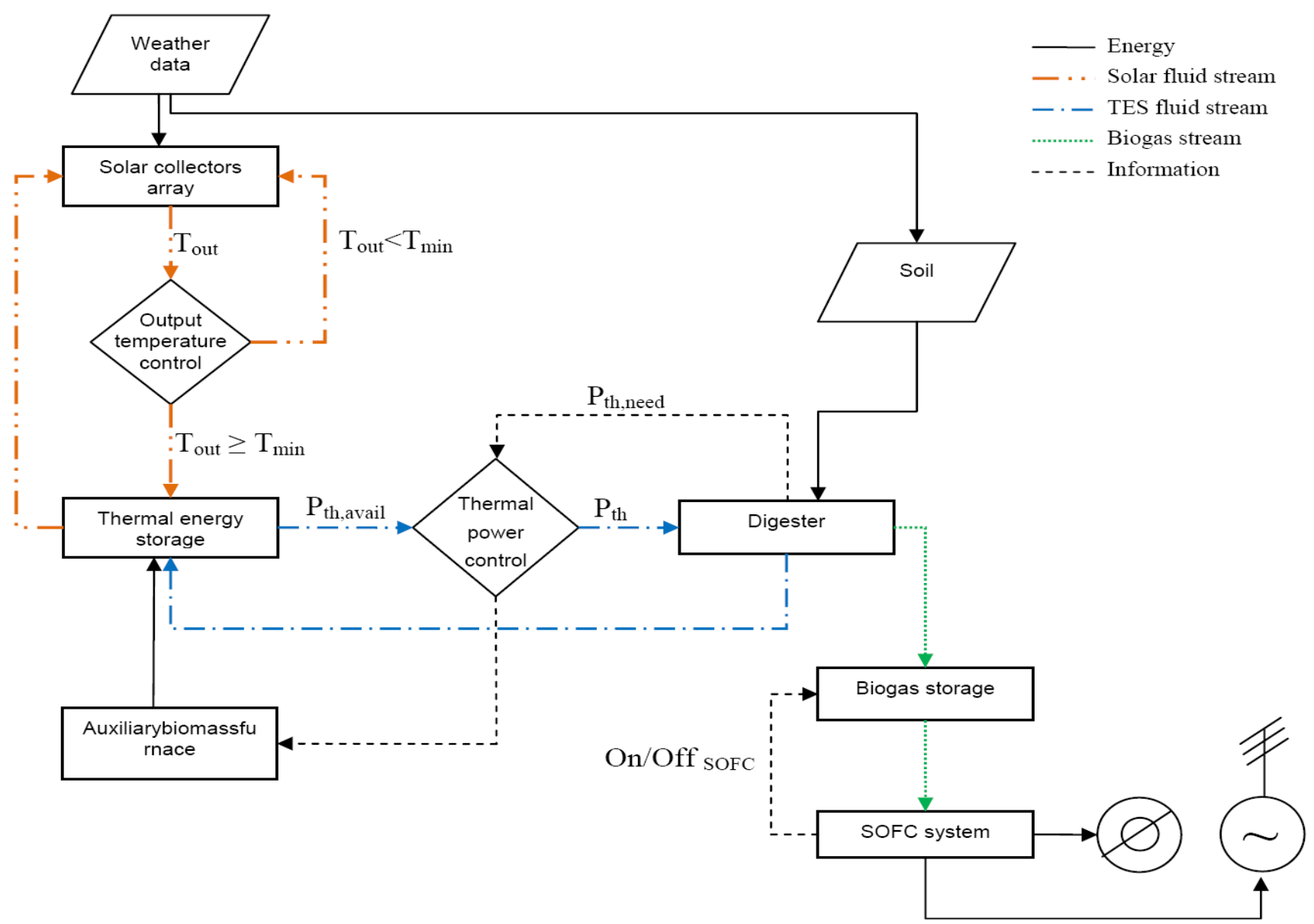

Figure 1.Flow diagram of the modelled transient energy conversion system.

The transient system layout is schematically shown in Figure 1. Besides the standard TRNSYS library components, the transient model also includes in-house made types for the digester, the biogas storage, the SOFC system (derived from Aspen Plus model) and the controls of output temperature and thermal power controls. The simulation is performed with an hourly time step over a reference year period.

The weather data object provide the solar radiation information to the solar collector array, which supplies the thermal energy to the TES. The operating conditions inside the digester require a constant inner temperature of $35^{\circ} \mathrm{C}$ irrespective of the climate conditions. It is worth noting that climate also influence the soil temperature. The digester needs to be warmed-up feeding thermal power from the TES to compensate the heat losses through the walls and to warm-up the substrate entering at environment (lower) temperature. As the solar section and the digester behaviour depend on the local meteorological conditions, their working results may differ from the design. To this end the temperature output of the solar collectors array and of the digester are controlled. In particular, the temperature control checks the exit temperature from the collectors at each time step, giving rise to two possible situations:

1. The outlet temperature $\left(\mathrm{T}_{\text {out }}\right)$ undergoes the fixed minimum temperature $\left(\mathrm{T}_{\min }\right)$, starting the flow recirculation into the solar field until it reaches a proper temperature;

2. The outlet temperature is higher than the fixed minimum temperature, allowing the flow to pass into the thermal energy storage.
In case the temperature inside the storage is higher than $100{ }^{\circ} \mathrm{C}$, the thermal heat will be dissipated. Finally, the thermal power control determines the fluid flow to be withdrawn from the TES and sent to the digester for maintaining mesophilic conditions. Moreover, when the thermal power control indicates that TES is getting too cold $\left(<60^{\circ} \mathrm{C}\right)$, a biogas furnace is switched on to supply the required heat.

The digester subroutine was designed following the hypothesis already described in (Sans et al., 1995), thus giving the geometrical parameters, the feeding material characteristics, the working temperature and the ambient temperature. It calculates the biogas production, the thermal losses and the thermal energy need to maintain the inner design operating temperature. The biogas storage subroutine takes the SOFC duty information and the input biogas flow-rate and manages the biogas supplied to the SOFC system in order to return a constant flow-rate. The SOFC system subroutine takes into account all the pretreatment elements described above and the SOFC itself.

\section{Components Description}

The thermal section of the energy system is composed by a solar collector array equipped with a thermal energy storage aiming at supplying thermal energy to maintain the digester at a constant inner temperature of $35^{\circ} \mathrm{C}$. The fuel obtained from anaerobic digestion is sent to a biogas storage and then fed the SOFC system in order to deliver heat and power to the final users. The main components sizes are summarized in Table 1. 
Table 1. Main components description and nominal size.

\begin{tabular}{ll}
\hline Solar collectors array & 280 collectors, $560 \mathrm{~m}^{2}$ \\
Thermal energy storage & $\begin{array}{l}15 \mathrm{~m}^{3} \mathrm{max} \text { energy supply } \\
345 \mathrm{kWh}\end{array}$ \\
$\begin{array}{l}\text { Digester } \\
\text { Biogas storage }\end{array}$ & $318 \mathrm{~m}^{3}$ volume \\
$\begin{array}{l}\text { Auxiliary TES heater } \\
\text { (biomass furnace) }\end{array}$ & $72,000 \mathrm{~kg}$ biogas \\
\hline
\end{tabular}

Input data: The input data (NREL, 2003) used for the simulation of the solar collectors are based on an hourly time step over a year period, referring to Rome's latitude, i.e. $41^{\circ} 54^{\prime} 39^{\prime \prime} 24 \mathrm{~N}$, as indicative of a central Italian location. The direct normal insulation (DNI) data show an annual cumulative irradiation of $5760 \mathrm{MJ} / \mathrm{m}^{2}$, with a maximum value of $733.68 \mathrm{MJ} / \mathrm{m}^{2}$ in July and a minimum value of $253.04 \mathrm{MJ} / \mathrm{m}^{2}$ in December. The weather data are read in TRNSYS by type 89 of the standard TRNSYS library (Klein et al., 2000). The monthly average environmental temperature, required to determine the heat losses of the digester is reported in Figure 2.

The waste considered in this study for the digestion process is the organic fraction of municipal solid waste. The organic substrate is defined by its Total Solid (TS) and Volatile Solid (VS) concentrations. In the present study a $15 \%$ TS and $80 \%$ VS substrate of a food industry-sorted organic waste is considered, following the study of Sans (1995). A continuous feeding schedule is set, with a loading rate of $7.27 \mathrm{t} / \mathrm{d}$ of OFMSW.

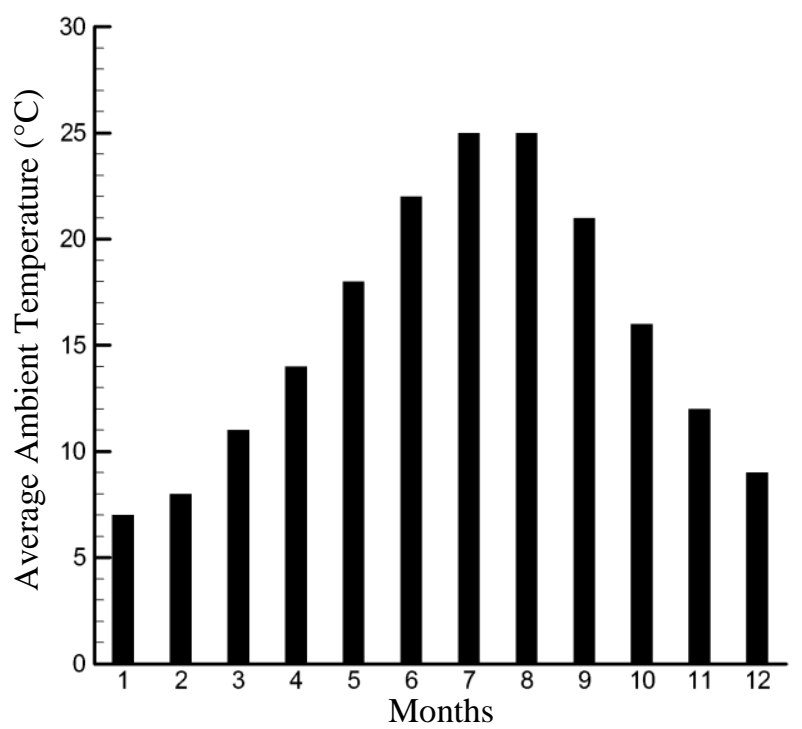

Figure 2. Ambient monthly average temperature behaviour (NREL, 2003).

Solar Field: The solar field is composed by 280 collectors distributed over 7 strings of 40 collectors each. The total collector area is of $560 \mathrm{~m}^{2}$. The fluid flowing through the solar circuit is water, with an overall flow rate of $700 \mathrm{~kg} / \mathrm{h}$. The thermal storage is a $4 \mathrm{~m}$ high tank with a volume of $15 \mathrm{~m}^{3}$. It is equipped with an auxiliary biomass furnace of $20 \mathrm{~kW}$ to compensate the solar source fluctuations and maintain a minimum fluid temperature of $60{ }^{\circ} \mathrm{C}$ inside the tank. The solar field is modelled by using the elements available in the standard TRNSYS library, in particular type 73 for the parabolic troughs, and type 60 for the thermal energy storage.

Anaerobic Digester: The Anaerobic Digester reactor (AD) is designed for a mesophilic temperature of $35^{\circ} \mathrm{C}$. The process considered is a single stage continuous-flow stirred tank reactor (CSTR), operating in wet regime, with total solids concentration less than $10 \%$, with an organic load equal to $5 \mathrm{kgVS} / \mathrm{m}^{3} \mathrm{~d}$ and a hydraulic retention time (HRT) of 15 days (Laraia, 2002). The digester is designed as a concrete reactor, with a polyurethane external insulation and steel internal layers, partially placed underground (4.5 $\mathrm{m})$. The top of the reactor consists of an elastic polyurethane surface. Table 2 shows the values used to design the reactor. Due to some uncertainty in the design process a safety factor equal to 1.2 is assumed. Then, the final volume of the digester is set equal to about $320 \mathrm{~m}^{3}$.

Table 2. Design parameters of anaerobic digester.

\begin{tabular}{lc} 
Diameter & $9 \mathrm{~m}$ \\
Overall height & $7 \mathrm{~m}$ \\
Organic Load Rate (OLR) & $5 \mathrm{kgVS} / \mathrm{m}^{3} \mathrm{~d}$ \\
HRT & 15 days \\
Safety factor & 1.2 \\
\hline
\end{tabular}

The AD heat demand is evaluated considering the heat for warming-up the inlet organic substrate assuming a specific heat of $1000 \mathrm{kcal} / \mathrm{m}^{3}{ }^{\circ} \mathrm{C}$ and the heat losses through the side walls. The top surface is considered adiabatic, while heat losses occur through the lateral and lower walls. Table 3 shows the parameters used and the heat losses evaluated in the digester through the bottom and lateral surfaces.

The digester is modelled in TRNSYS with an in-house made type which asks for the ambient and soil temperature and the OFMSW flow rate, returning the produced biogas flow rate and the needed heat to maintain the digester inner temperature of $35^{\circ} \mathrm{C}$. The soil temperature is obtained by type 501, which is the soil temperature profile component of the TESS TRNSYS library (TESS, www.trnsys.com).

Table 3. Parameters and power loss in the digester.

\begin{tabular}{ll} 
Ground surfaces heat transfer coeff. & $0.22 \mathrm{~W} / \mathrm{m}^{2 \circ} \mathrm{C}$ \\
Air surfaces heat transfer coefficient & $0.5 \mathrm{~W} / \mathrm{m}^{2 \circ} \mathrm{C}$ \\
Overall power losses & $1.657 \mathrm{~kW}$ \\
\hline
\end{tabular}

Biogas storage: The biogas storage is inserted into the system with the aim to decouple the biogas production from the fuel consumption inside the SOFC. In fact, the digester process is continuously working and producing biogas (except for small maintenance periods) due for the treatment of the OFMSW.

On the other hand, the SOFC requires more frequent stops for maintenance and then the storage has to be designed in order to compensate the difference in biogas production and consumption. To guarantee safe operating conditions the storage is designed to allow biogas accumulation for $1000 \mathrm{~h}$ during the SOFC inactivity period and to gradually return it during the SOFC activity period, in order to feed the SOFC with a constant biogas flow-rate. The biogas storage capacity is equal to $42,800 \mathrm{~kg}$ of biogas. The biogas storage is modelled in TRNSYS with an in- 
house made type, which just computes the amount of biogas stored in the tank in relation with the SOFC duty.

SOFC: The energy system used for electricity and thermal power source consists of a SOFC of $150 \mathrm{~kW}_{\mathrm{el}}$ size. The mass and energy flows into the SOFC are analysed by using the Aspen Plus ${ }^{\mathrm{TM}}$ software, which is successfully used for simulating fuel cells based energy systems (Zhang et al., 2005), (Borello et al., 2012). In Aspen Plus the most SOFC systems are simulated by user models (Doherty et al., 2010), (Kim et al., 2011), (Kuchonthara et al., 2003) and only a few are modelled using standard library elements of Aspen Plus (Quesada et al., 2011), (Barelli et al., 2011).

The system is fed by a biogas with a mole based composition of $8 \% \mathrm{H}_{2}, 60 \% \mathrm{CH}_{4}$ and $32 \% \mathrm{CO}_{2}$ and a low heating value of $21,600 \mathrm{~kJ} / \mathrm{m}^{3}$. The SOFC model flow sheet, Figure 3, includes all the components and functions contained in the system. It is worth noting that the software does not have the fuel cell component and then all the processes and reactions occurring in a SOFC are modelled separately. The fuel coming from the biogas storage is mixed with the recirculating fluid coming from the fuel cell (see blue dashed box) for obtaining a steam to carbon ratio equal to 2.5 that is considered optimal for SOFC (Zhang et al., 2005).

The steam reforming process occurs at a temperature of $600^{\circ} \mathrm{C}$. A constant temperature is imposed in the reformer to control the process and then two heat exchangers are introduced control the fuel temperature before and after the reformer as well as to feed the reformer with the required heat. Most of the needed heat comes from the SOFC cooling (thermal stream Q3). Downstream from the reformer the fuel is mainly composed by $\mathrm{H}_{2}, \mathrm{CO}$ and $\mathrm{CO}_{2}$, with traces of methane, butane and propane.

In the SOFC, a flux of oxygen flows through stream 6 from cathode to anode and it reacts here with the $\mathrm{CO}$ and $\mathrm{H}_{2}$ at $1000{ }^{\circ} \mathrm{C}$. Energy stream $\mathrm{Q}_{2}$ contains both the electricity produced and the waste heat. The flow exiting the anode contains some fuel not burned in order to guarantee safe operating working conditions to the cell (if all the fuel is consumed near the cell exits the reaction does not occur anymore and then the voltage becomes rapidly zero).

The fluid leaving the SOFC is split in two streams: the first one mixes with the inlet fuel and it is calibrated to guarantee a $\mathrm{S} / \mathrm{C}$ ratio of 2.5 ; the second one, having some fuel remaining, is sent to an afterburner devoted to increase the exhaust outlet temperature. The high energetic content of the exhausts is then used to pre-heat the air entering the cathode and to feed the thermal user, i.e. district heating.

The in-house made TRNSYS model of the SOFC system takes into account the entire Aspen Plus model in a single type, based on an empirical relationship, obtained by a sensitivity analysis of the Aspen Plus SOFC model. The sensitivity analyses are conducted with the hypothesis that a $12.57 \mathrm{~kW}$ constant heat power output must be available for the district heating. In particular the obtained relations give the values of the hydrogen utilization factor (Uf) at the SOFC and the electric power output $\left(\mathrm{P}_{\mathrm{el}}\right.$, in $\left.\mathrm{W}\right)$ related to the biogas flow rate $\left(\mathrm{m}_{\mathrm{b}}\right.$, in $\left.\mathrm{kg} / \mathrm{h}\right)$ supplied to the SOFC system inlet: $\mathrm{Uf}=0.0255 \mathrm{~m}_{\mathrm{b}}$ and $\mathrm{P}_{\mathrm{el}}=134.52 \mathrm{~m}_{\mathrm{b}}^{2}$.

\section{Results}

The global results of the transient simulation are shown in Table 4. As can be seen, the solar field receives about $3550 \mathrm{GJ} / \mathrm{y}$ with a global solar energy availability of 4679 hours. The heat effectively supplied to the TES from the solar field amounts to $134.62 \mathrm{GJ} / \mathrm{y}$ which is about $3.8 \%$ of the incident solar energy. Such a low percentage of supplied energy is an effect of the fluid recirculation into the collectors when the solar radiation is not high enough to determine a fluid temperature that is adequate to feed the TES (i.e. greater than $70^{\circ} \mathrm{C}$ ). In a successive development step recirculation will be avoided and the fluid will pass through the auxiliary heater to be eventually heated up to the TES inlet temperature.

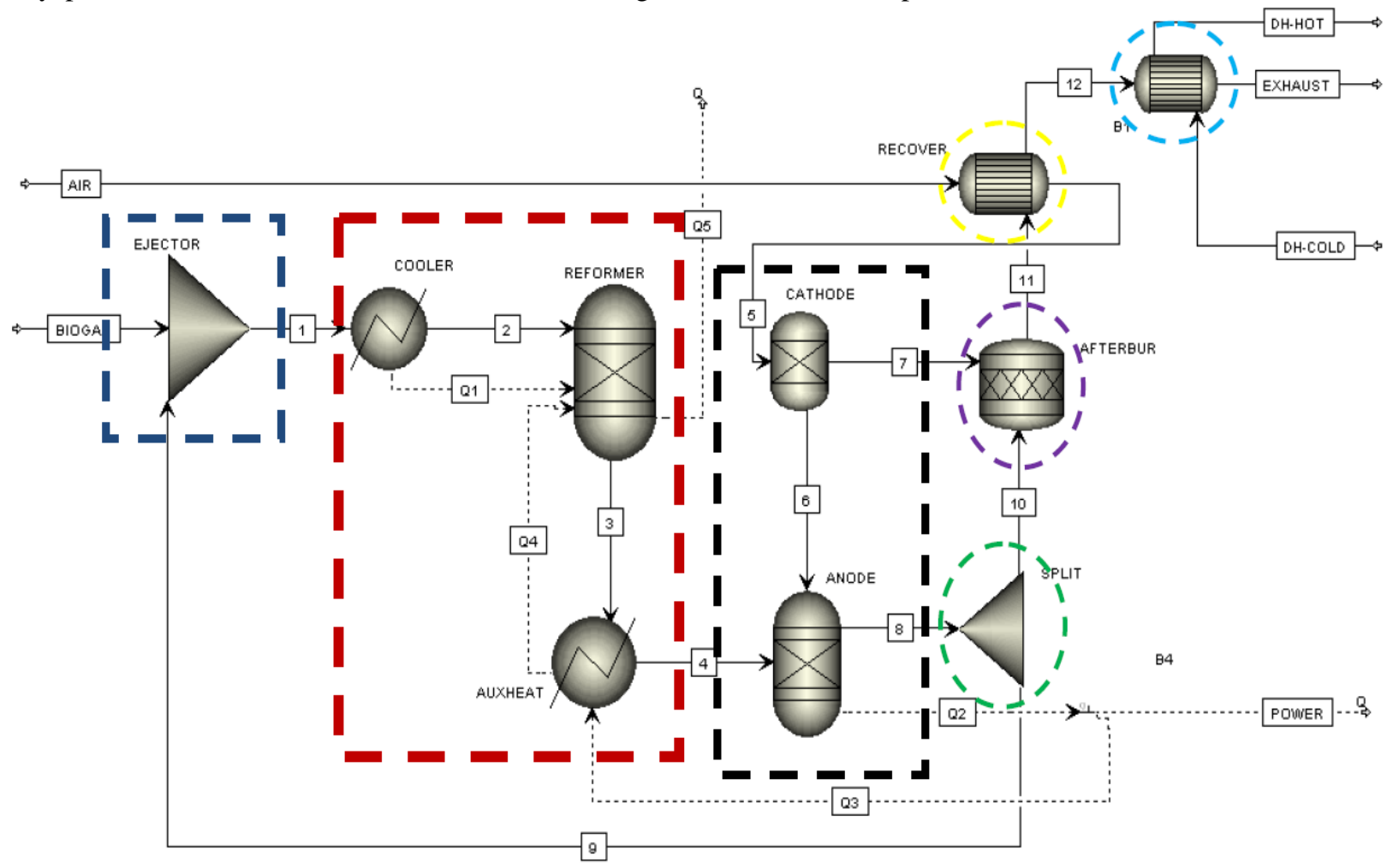

Figure 3. Aspen Plus ${ }^{\mathrm{TM}}$ SOFC model flowsheet. 
Table 4. Overall results.

\begin{tabular}{|c|c|c|}
\hline \multirow[t]{3}{*}{ Solar field } & $\begin{array}{l}\text { Incident solar energy }[\mathrm{GJ} / \mathrm{y}] \\
\text { Hours with incident solar energy }[\mathrm{h} / \mathrm{y}]\end{array}$ & $\begin{array}{l}3,552.51 \\
4679\end{array}$ \\
\hline & Solar energy exchanged with the TES [GJ/y] & 134.62 \\
\hline & Hours of thermal energy supply to the TES [h/y] & 1513 \\
\hline \multirow[t]{6}{*}{ TES } & Auxiliary TES heat $[\mathrm{GJ} / \mathrm{y}]$ & 194.98 \\
\hline & Auxiliary TES heater duty hours $[\mathrm{h} / \mathrm{y}]$ & 3652 \\
\hline & Energy supplied to the digester by the TES [GJ/y] & 269.03 \\
\hline & Average tank temperature $\left[{ }^{\circ} \mathrm{C}\right]$ & 75.39 \\
\hline & Average top tank temperature $\left[{ }^{\circ} \mathrm{C}\right]$ & 82.58 \\
\hline & Average bottom tank temperature $\left[{ }^{\circ} \mathrm{C}\right]$ & 63.28 \\
\hline \multirow[t]{4}{*}{ Digester } & Heat loss of the digester [GJ/y] & 37.39 \\
\hline & Heat need of the substrate[GJ/y] & 231.61 \\
\hline & Global heat demand of the digester [GJ/y] & 269.03 \\
\hline & Biogas production [ton/y] & 239.96 \\
\hline \multirow[t]{5}{*}{ SOFC system } & Biogas supply to SOFC [ton/y] & 233.75 \\
\hline & SOFC duty hours $[\mathrm{h} / \mathrm{y}]$ & 7,000 \\
\hline & SOFC thermal energy output $[\mathrm{GJ} / \mathrm{y}]$ & 316.77 \\
\hline & SOFC electric energy output $[\mathrm{GJ} / \mathrm{y}]$ & $3,779.51$ \\
\hline & SOFC electrical efficiency & $55 \%$ \\
\hline
\end{tabular}

Assuming that the solar contribution is available only on daytime the TES requires an auxiliary heat of $194.98 \mathrm{GJ} / \mathrm{y}$ during 3652 duty hours (including hours when both systems are working). Taking into account the variable heat supply and withdrawal to the TES, the average TES temperature at the tank top and bottom amount respectively to $82.58^{\circ} \mathrm{C}$ and $63.28^{\circ} \mathrm{C}$. The heat to be supplied to the digester to maintain the temperature of $35^{\circ} \mathrm{C}$ required from the mesophilic digestion is equal to $269.03 \mathrm{GJ} / \mathrm{y}$. The produced biogas is about 240 ton/y, with a constant hourly output of $27.39 \mathrm{~kg} / \mathrm{h}$.

During the SOFC off-duty time the biogas output from the digester is sent to a biogas storage which, during the SOFC on-duty time releases an hourly rate of $6 \mathrm{~kg} / \mathrm{h}$ to the SOFC. The SOFC is fed with 233.75 ton/year of biogas with a constant hourly delivery, during the on-duty time, of $33.39 \mathrm{~kg} / \mathrm{h}$ deriving partly from the digester and partly from the biogas storage. The SOFC output is of about $317 \mathrm{GJ} / \mathrm{y}$ of thermal energy and 3,780 GJ/y of electric energy. According to the system design hypothesis, the only sections which behave in a transient fashion are those directly linked to the solar collectors field, thus the collectors field itself, the TES, the biomass furnace and the digester. Figure 4 shows the thermal power requested by the digester on an hourly-based time. The requested thermal energy is obviously higher in the winter period, when the difference between the design temperature and the ambient temperature is higher, reaching power needs of about 20 $\mathrm{kW}$. In some hours of the summer period the temperature difference leads to power request lower than $1 \mathrm{~kW}$. The continuous variation of the request during the whole year corresponds to the alternation of day and night time.

Such a variable demand, matched with the transient behaviour of the solar thermal energy supply (which is higher during the summer period) leads to a continuous variation of the temperatures in the TES tank. Figure 5 shows the pattern of the top and bottom temperature of the tank. At the bottom of the tank, the minimum temperature is always higher than $59.40^{\circ} \mathrm{C}$ and the maximum is equal to $82.88^{\circ} \mathrm{C}$. At the top of the tank, the minimum temperature is $68.46^{\circ} \mathrm{C}$ ant the maximum is $100^{\circ} \mathrm{C}$.

Figure 6 shows the thermal energy balance of the TES. As already stated, the digester needs a lower amount of thermal energy during the summer period with respect to the winter one. The thermal energy supplied by the TES $\left(Q_{\text {sup }}\right)$ follows the request of thermal energy from the digester. Moreover, the seasonal behaviour of the solar energy supply $\left(Q_{R E S}\right)$ influences the auxiliary thermal supply $Q_{a u x}$ (i.e. the biomass furnace) performance, which shows an inverted seasonal pattern. It is worth noting that the sum of the thermal energy delivered to the TES (i.e. $Q_{R E S}$ and $\left.Q_{a u x}\right)$ is higher than the supplied thermal energy to the digester from the TES $\left(Q_{\text {sup }}\right)$. This is due to the need to maintain the minimum temperature of $60^{\circ} \mathrm{C}$ in the TES itself in order to assure the thermal supply when needed. During the summer period, in the months of July and August, the solar collector field thermal energy supply is almost sufficient to satisfy the thermal request of the digester.

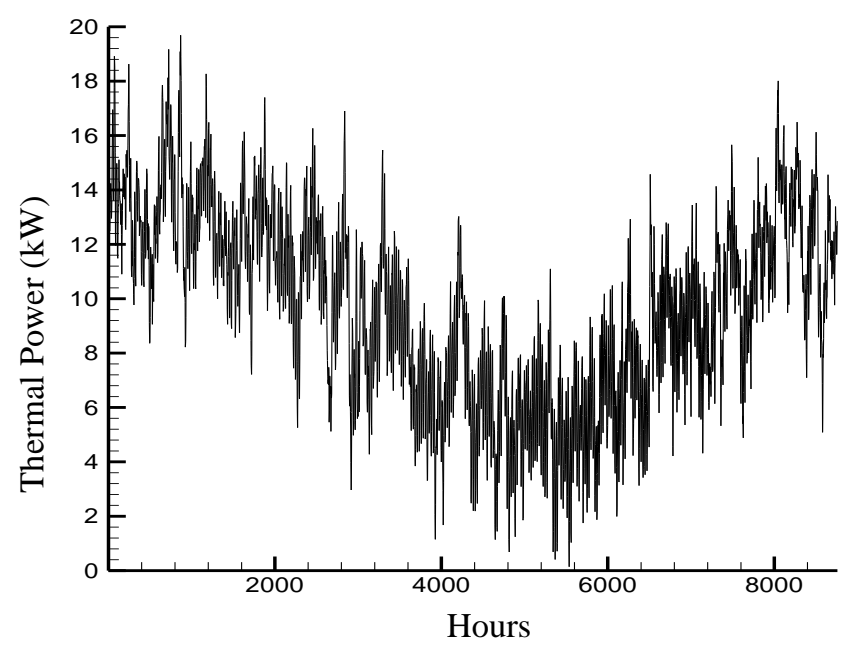

Figure 4. Thermal power request from the digester. 


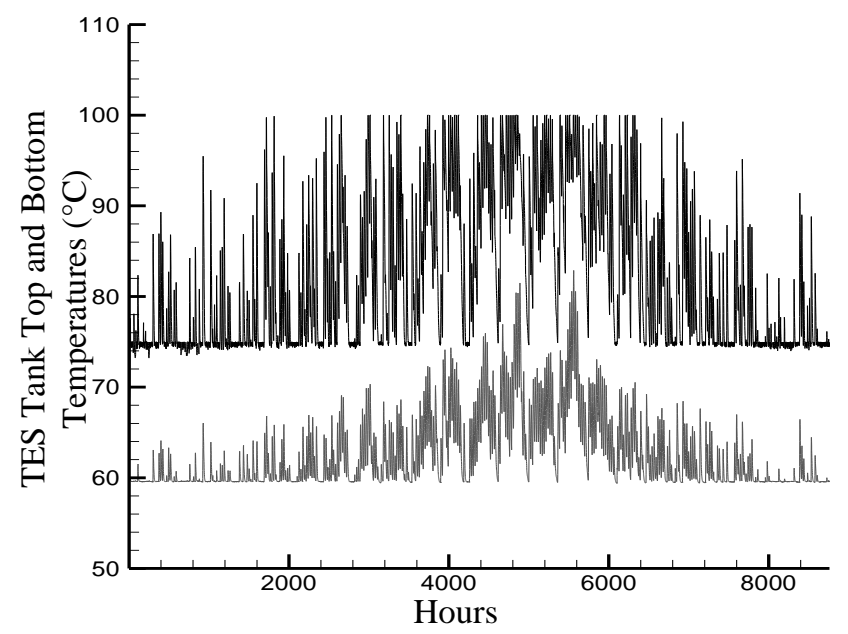

Figure 5. TES top tank temperature (black line) and bottom temperature (grey line).

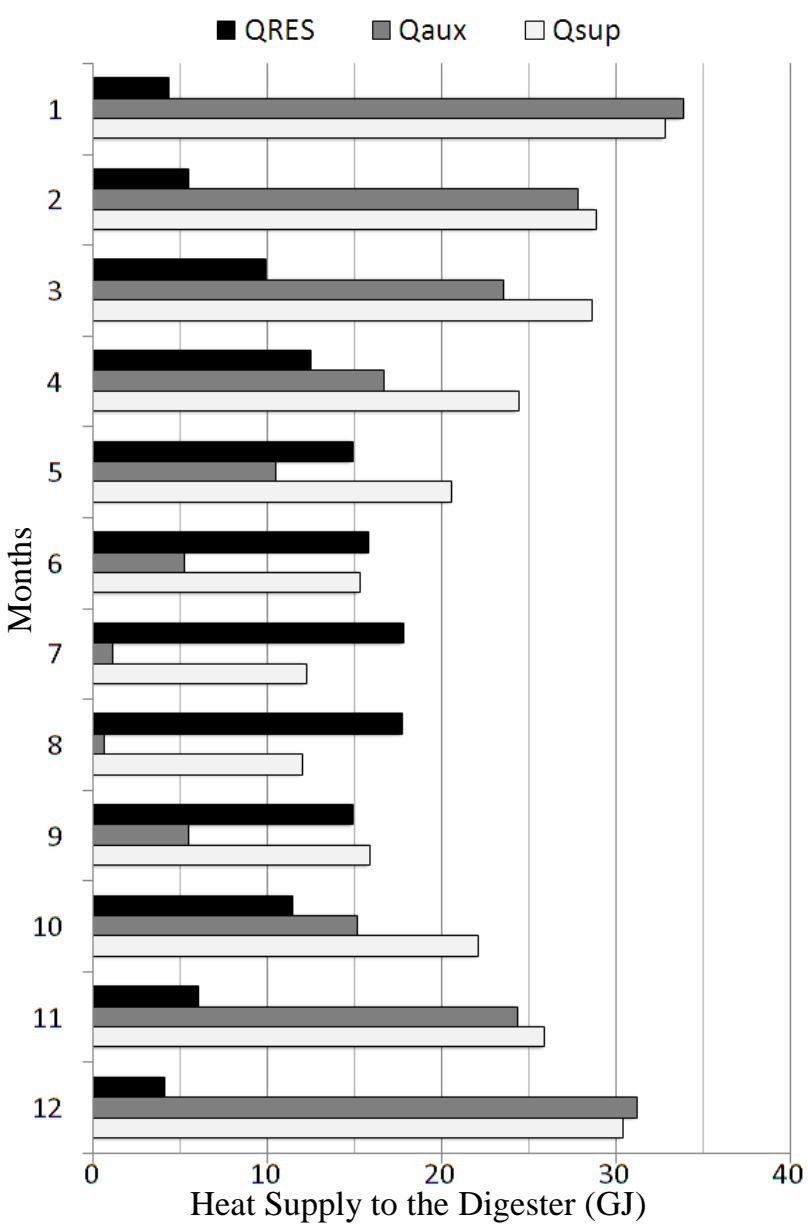

Figure 6. TES thermal energy contribution.

\section{Environmental aspects}

A fundamental aspect of a new energy plant is its capability to save greenhouse gas emissions. In particular 1 ton of waste not sent to landfill helps to save $1120 \mathrm{~kg}_{\mathrm{CO} 2 \mathrm{eq}}$. For the present plan, which uses 2654.3 ton ofMsw/year, the emissions saving corresponds to 2972.82 ton $_{\mathrm{CO} 2 \mathrm{eq}} /$ year. Moreover, the emission factor related to the Italian thermoelectric power stations at reference year 2009 (ISPRA, 2011) is of $523.4 \mathrm{~g}_{\mathrm{CO} 2} / \mathrm{kWh}$; this value leads to a $\mathrm{CO}_{2}$ emission saving of 549.50 ton $_{\mathrm{CO} 2} /$ year.

\section{Conclusions}

A transient model for the simulation of a biogas fuelled CHP $150 \mathrm{~kW}_{\mathrm{el}}$ plant was presented. The integrated renewable sources power plant here described has the potential to achieve high generation efficiencies as well as important environmental benefits through the mitigation of greenhouse gas emissions. The biogas is produced by an anaerobic digester processing OFMSW. The heat required to warm the substrate and to compensate losses is obtained by a solar field integrated by an auxiliary biomass furnace. The biogas produced is sent to a SOFC for co-generation of electricity and heat for possible use in a district heating (not modelled here). A large fraction of the produced heat is used for pre-heating the SOFC plant, so only $10 \%$ of the available heat is available for end users.

The transient model shows that the heat supplied to the digester by the solar field allows a saving of $7.63 \mathrm{ton} / \mathrm{y}$ of biogas - or the $4 \%$ of the total biogas production, equal to $131 \mathrm{GJ} / \mathrm{y}$ of electricity energy produced by the SOFC. Further improvements are in progress. A positioning of the solar field on the top of the digester as cover for the gas holder will allow a more efficient heat supply system for the digester. Moreover different type of solar collectors with higher energy efficiency could totally substitute the biogas furnace, with considerable economic saving.

The whole system adopts a mix of renewable technologies to produce electricity and thermal power. This approach indicates a 'smart' solution for the disposal of organic fraction of municipal solid waste, allowing to define a fully sustainable chain from waste to energy.

\section{References}

Ackermann T., Andersson G., Sode, L., (2001), Distributed generation: a definition. Electric Power Systems Research, 57, 195-204.

Alanne, K., Saari, A., (2006), Distributed energy generation and sustainable development. Renewable and Sustainable Energy Reviews, 10, 539-558.

Alkhamis, T.M., El-khazali, R., Kablan, M.M., Alhusein, M.A., (2001), Heating of a biogas reactor using a solar energy system with temperature control unit. Solar Energy, 69 (3), 239-247.

Axaopoulos, P., Panagakis, P., Tsavdaris, A., Georgakakis, D., (2001), Simulation and experimental performance of a solar heated anaerobic digester. Solar Energy, 70 (2), $155-164$.

Barelli, L., Bidini, G., Gallorini, F., Ottaviano, A., (2011), An energetic-exergetic comparison between PEMFC and SOFC-based micro-CHP systems. International Journal of Hydrogen Energy, 36(4), 3206-3214.

Borello, D., Del Prete, Z., Marchegiani, A., Rispoli, F., Tortora, E., (2012), Analysis of an integrated PEMFC/ORC power system using ammonia for hydrogen storage, ASME Turbo Expo 2012, GT201268599, Copenhagen, 11-15 June, 2012.

Commission of the European Community, Investing in the Development of Low Carbon Technologies (SET-Plan), October 2009, COM (2009) 519.

Calise, F., Dentice D’Accadia, M., Palombo, A., Vanoli, L., (2006), Simulation and exergy analysis of a hybrid Solid Oxide Fuel Cell (SOFC)-Gas Turbine System. Energy, 31 (15), 3278-3299

Calise, F., (2011), Design of a hybrid polygeneration system with solar collectors and a Solid Oxide Fuel 
Cell: Dynamic simulation and economic assessment. International Journal of Hydrogen Energy, 35, 61286150 .

Commission of the European Community, A European Strategic Energy Technology Plan (SET-PLAN): 'Towards a low carbon future', November 2007, COM (2007) 723.

Corsini, A., Rispoli, F., Gamberale, M., Tortora, E., (2009), Assessment of H2- and H2O-based renewable energybuffering systems in minor islands. Renewable Energy, 34, 279-288.

Directive 2002/91/EC of the European Parliament and of the Council of 16 December 2002 on the energy performance of buildings.

Directive 2006/32/EC of the European Parliament and of the Council of 5 April 2006 on energy end-use efficiency and energy services and repealing Council Directive 93/76/EEC.

Directive 2009/28/EC of the European Parliament and of the Council of 23 April 2009 on the promotion of the use of energy from renewable sources and amending and subsequently repealing Directives 2001/77/EC and 2003/30/EC

Doherty W., Reynolds A., Kennedy D., (2010), Computer simulation of a biomass gasification-solid oxide fuel cell power system using Aspen Plus. Energy, 35, 45454555 .

Dorer V., Weber R., Weber A., (2005), Performance assessment of fuel cell micro-cogeneration systems for residential buildings. Energy and Buildings, 37 (11), $1132-1146$.

Elkhattam W., Salama M. M. A., (2004), Distributed generation technologies, definitions and benefits.Electric Power Systems Research, 71 (2), 119 128 .

Eriksson, O., Bisaillon, M., Haraldsson, M., Sundberg, J., (2011), Integrated waste management as a mean to promote renewable energy. World Renewable Energy Congress, 8-11 May 2011, Sweden.

European Commission C(2011)9493 of 20 December 2011 , Work Programme, Theme 5 - Energy.

Gregg. J., (2010), National and regional generation of municipal residue biomass and the future potential for waste-to-energy implementation. Biomass and Bioenergy, 34 (3), 379-388.

ISPRA Superior Institute for the Environmental Protection and Research (2011), Produzione termoelettrica ed emission di CO2, Rapporti 135/2011, Rome, (in Italian).

Kim, Y., Hong, S., Nam, S., Seo, S., Yoo, Y., Lee, S., (2011), Development of $1 \mathrm{~kW}$ SOFC power package for dual-fuel operation. International Journal of Hydrogen Energy, 36, 10247-10254.
Klein, S.A., Beckam, W.A., Mitchell, J.W., Braun, J.E., Evans B.L., Kummert J.P., et al., (2000), "TRNSYS - a transient system simulation program. Version 15.1", Madison: Solar Energy Laboratory, University of Wisconsin.

Kuchonthara, P., Bhattacharya, S., Tsutsumi, A., (2003), Energy recuperation in solid oxide fuel cell (SOFC) and gas turbine (GT) combined system. Journal of Power Sources, 117(1-2), 7-13.

Laraia, R., (2002), "Il trattamento anaerobico dei rifiuti", Manuali e Linee Guida 13 - ANPA Unita' Normativa Tecnica, (in Italian).

Larminie, J., Dicks, A., (2004) "Fuel cell system explained".The Atrium, Southern Gate, Chichester,West Sussex: John Wiley \& Sons Ltd.

Liso V., Zhao Y., Brandon N., Nielsen M. P., and Kær S. K., (2011), Analysis of the impact of heat-to-power ratio for a SOFC-based $\mathrm{mCHP}$ system for residential application under different climate regions in Europe. International Journal of Hydrogen Energy, 36 (21), 13715-13726

Manfren M., Caputo P., Costa G., (2011), Paradigm shift in urban energy systems through distributed generation: Methods and models. Applied Energy, 88, 1032-1048.

Morin, P., Marcos, B., Moresoli, C., Laflamme C.B., (2010), Economic and environmental assessment on the energetic valorisation of organic material for a municipality in Quebec, Canada. Applied Energy, 87 (1), 275-283.

NREL Solar Energy Laboratory, University of WisconsinMadison, (2003), "Generated hourly weather data".

Quesada, B., Sánchez, C., Cañada, J., Royo, R., Payá, J., (2011), Experimental results and simulation with TRNSYS of a $7.2 \mathrm{kWp}$ grid-connected photovoltaic system. Applied Energy, 88 (5), 1772-1783.

Sans, C., Mata-Alvarez, J., Cecchi, F., Pavan, P., Bassetti, A., (1995), Volatile fatty acids production by mesophilic fermentation of mechanically sorted urban organic wastes in a plug flow reactor. Bioresource Technology, 51, 89-96.

Shiratori Y., Oshima T., Sasaki K., (2008), Feasibility of direct-biogas SOFC. International Journal of Hydrogen Energy, 33 (21), 6316-6321.

Strachan, N., Farrell A., (2006), Emissions from distributed vs. centralized generation: The importance of system performance. Energy Policy, 34, 2677-2689.

Zhang, W., Croiset, E., Douglas, P.L., Fowler, M.W., Entchev, E., (2005), Simulation of a tubular solid oxide fuel cell stack using Aspen Plus ${ }^{\mathrm{TM}}$ unit operation models. Energy Conversion and Management, 46, 181196. 